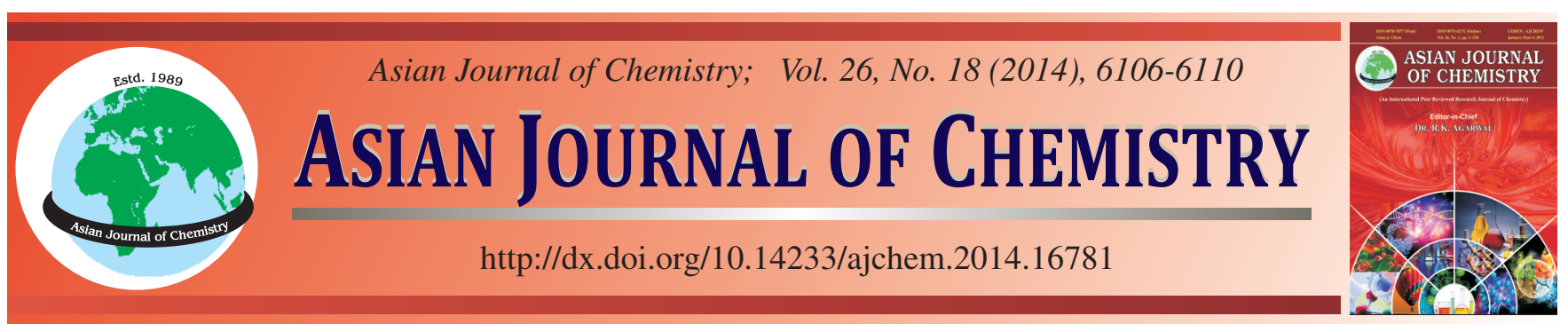

\title{
bis-Hydrazine Metal and Mixed Metal $m$-Nitrobenzoates: Synthesis, Spectral, Thermal and X-ray Diffraction Studies
}

\author{
D. Santhosh ShanthakUmaR ${ }^{1, *}$ and B.N. SivasankaR ${ }^{2}$
}

${ }^{1}$ Department of Chemistry, Sri Krishna College of Technology, Kovaipudur, Coimbatore-641 042, India

${ }^{2}$ Department of Chemistry, Government Arts College, Udhagamandalam, The Nilgiris-643 002, India

*Corresponding author: E-mail: sivabickol@yahoo.com

\begin{abstract}
bis-Hydrazine metal(II) $m$-nitrobenzoates, $\left[\mathrm{M}\left(m-\mathrm{NO}_{2} \mathrm{C}_{6} \mathrm{H}_{4} \mathrm{COO}\right)_{2}\left(\mathrm{~N}_{2} \mathrm{H}_{4}\right)_{2}\right]$, where $\mathrm{M}=\mathrm{Co}, \mathrm{Ni}, \mathrm{Zn}$ or Cd have been prepared by the stoichiometric reaction between the aqueous solution of respective metal nitrate hydrate with aqueous solution containing a mixture of $m$-nitrobenzoic acid and hydrazine hydrate in appropriate ratio. These complexes have been characterised by analytical, spectral, thermal and X-ray powder diffraction studies. The IR spectra indicate the bridging bidentate nature of hydrazine moieties and monodentate nature of carboxylate ions. All these complexes except zinc complex undergo one step decomposition to yield respective metal oxide as the final product. However, the zinc complex undergoes dehydrazination in the first step followed by ligand pyrolysis to give $\mathrm{ZnO}$ as the final residue. X-ray powder diffraction patterns indicate that the complexes are isomorphous. The mixed metal complexes, $\left[\mathrm{M}_{1 / 3} \mathrm{Co}_{2 / 3}(m-\right.$ $\left.\mathrm{NO}_{2} \mathrm{C}_{6} \mathrm{H}_{4} \mathrm{COO}\right)_{2}\left(\mathrm{~N}_{2} \mathrm{H}_{4}\right)_{2}$ ] have also been prepared using aqueous solution containing a mixture of metal nitrate hydrates and cobalt nitrate hexahydrate in 1:2 ratio instead of metal nitrate hydrate. These complexes on thermal degradation yield respective metal cobaltites as the final product. The formations of these cobaltites were confirmed by chemical analysis, IR spectra and X-ray powder diffraction studies.
\end{abstract}

Keywords: bis-Hydrazine, $m$-Nitrobenzoic acid, Mixed metal complexes, Metal cobaltites, TG-DTA and X-ray powder diffraction.

\section{INTRODUCTION}

Aromatic compounds containing nitro group are used as an explosives due to their vigorous decompositions at lower temperatures. The coordination compound containing nitro group also exhibits the same thermal behaviours. There are a large number of simple metal complexes containing nitro benzoic acid and their derivatives are thoroughly investigated ${ }^{1-7}$. Despite this, there is no report on the corresponding hydrazine analogue.

Hydrazine is used in various fields for diverse applications. Coordination compounds containing hydrazine receive much attention during the recent year due to its ability to coordination and high thermal reactivity. This low temperature decomposition has been attributed to the endothermic nature of N-N bond of hydrazine, which release enormous amount of energy in the form of heat during its thermal cleavage. This energy is utilized for the decomposition of remaining part of the complex into oxides, mixed metal oxides even into metal powder. In coordination complexes hydrazine shows different behaviour towards metal ions such as neutral monodentate, bidentate and bridged bidentate ligand. In weakly acidic medium it also generates hydrazinium cation. The nature of complex formed mainly depends on the nature of hydrazine moiety in it. The presence of these two groups such as nitro group and hydrazine in a same complex largely enhances their thermal reactivity. These properties provide access for the preparation of fine metal oxides at much lower temperatures with high purity.

Review of literature clearly reveals that substantial amounts of work have been done on transition metal ${ }^{8-14}$ and lanthanide carboxylates ${ }^{15-17}$ containing neutral hydrazine and hydrazine cation. However, only a few aromatic carboxylic acid complexes have been investigated ${ }^{18-20}$. Besides this the mixed metal complexes containing hydrazine have also been prepared for a few hydrazine metal carboxylates and have been used as the precursors to the metal cobaltites and metal ferrites $^{21-24}$. Hence, it is also expected that the hydrazine mixed metal meta-nitrobenzoate could be prepared and possibly used as the solid solution precursors for fine mixed metal oxides. In the present investigation attempt has been made to prepare metal hydrazine and mixed metal hydrazine complexes with meta-nitrobenzoic acid. In this paper, we wish to report the synthesis, characterization, spectral, thermal and X-ray diffraction pattern of bis-hydrazine metal and mixed metal $m$-nitrobenzoates. 


\section{EXPERIMENTAL}

Preparation of bis-hydrazine metal $\boldsymbol{m}$-nitrobenzoates and mixed metal $\boldsymbol{m}$-nitrobenzoates: bis-Hydrazine metal $m$-nitrobenzoate complexes were prepared by adding an aqueous solution containing a mixture of $m$-nitrobenzoic acid $(10 \mathrm{~g}$, $0.06 \mathrm{~mol})$ and hydrazine hydrate $(6 \mathrm{~mL}, 0.12 \mathrm{~mol})$ to an aqueous solution $(50 \mathrm{~mL})$ of respective metal nitrate hydrate $(0.03 \mathrm{~mol})$ slowly with constant stirring. The resulting solution obtained was filtered and allowed to stand at room temperature for crystallization. The crystalline precipitate formed after 5-6 h was filtered, washed with water then with alcohol and dried in air.

The mixed metal complexes were prepared by the same procedure described as above by using mixture of respective metal nitrate hydrate $(0.01 \mathrm{~mol})$ and cobalt nitrate hexahydrate $(0.02 \mathrm{~mol})$ instead of metal nitrate hydrate. The amounts of metal nitrates used are as follows. Cobalt nitrate hexahydrate (5.82 g, $0.02 \mathrm{~mol})$, nickel nitrate hexahydrate $(2.59 \mathrm{~g}, 0.01$ $\mathrm{mol})$, Zinc nitrate hexahydrate $(2.97 \mathrm{~g}, 0.01 \mathrm{~mol})$ and cadmium nitrate hexahydrate $(3 \mathrm{~g}, 0.01 \mathrm{~mol})$.

Physico-chemical studies: The hydrazine content in the complexes was determined volumetrically using $\mathrm{KIO}_{3}$ solution $(0.025 \mathrm{~mol})$ under Andrew's condition. The metal content in all the complexes were determined by EDTA complexometric titrations after decomposing a known amount of the complex with concentrated nitric acid ${ }^{25}$. The cobalt content in mixed metal complexes were determined by separating cobalt as $\mathrm{Co}\left(\mathrm{C}_{10} \mathrm{H}_{6} \mathrm{ONO}\right)_{3}$ complex using $\alpha$-nitroso $\beta$-naphthol after decomposing a known amount of sample with concentrated nitric acid and evaporating the clear solution to dryness ${ }^{26}$. The filtrate during the separations containing $\mathrm{Ni}, \mathrm{Zn}$ or $\mathrm{Cd}$ has treated with chloroform to remove excess $\alpha$-nitroso $\beta$-naphthol and the metal ions were estimated by titration with standard EDTA solution ${ }^{25}$.

Room temperature magnetic measurements were carried out by Gouy balance using $\mathrm{Hg}\left[\mathrm{Co}(\mathrm{SCN})_{4}\right]$ as a calibrant. The solid state electronic absorption spectra of the complexes in Nujol mull were recorded on a Varian Cary 5000 UV-visible spectrophotometer in the range $200-800 \mathrm{~nm}$. A Perkin-Elmer CHN analyser (Model 1240) was used for C, H and N analysis. The IR spectra of the complexes were recorded on a SHIMADZU spectrophotometer using $\mathrm{KBr}$ pellets in the range 4000-400 $\mathrm{cm}^{-1}$. The simultaneous TG-DTA of the complexes in air was carried out using TG/DTA 6200 Thermal Analyser. The thermal experiments were performed in air with heating rate of $10^{\circ} \mathrm{C}$ $\min ^{-1}$ using platinum cups as sample holders. X-ray powder diffraction pattern of samples were obtained using Bruker D8
Focus Diffractometer with scan speed 5 seconds per step, using $\mathrm{CuK}_{\alpha}$ radiation $(\lambda=1.540598 \AA)$ and Scintillation counter as a detector.

\section{RESULTS AND DISCUSSION}

bis-Hydrazine metal $m$-nitrobenzoates were prepared by the reaction between respective metal nitrate hydrate and $m$ nitrobenzoic acid in the presence of excess of hydrazine hydrate in aqueous medium. The mixed metal $m$-nitrobenzoate complexes were prepared by the similar procedure using a mixture of metal nitrate hydrate and cobalt nitrate hexahydrate in appropriate ratio. The chemical reactions are represented as follows.

$3 \mathrm{M}\left(\mathrm{NO}_{3}\right)_{2} \cdot \mathrm{nH}_{2} \mathrm{O}+6 \mathrm{C}_{6} \mathrm{H}_{4}\left(\mathrm{NO}_{2}\right) \mathrm{COOH}+12 \mathrm{~N}_{2} \mathrm{H}_{4} \cdot \mathrm{H}_{2} \mathrm{O} \rightarrow$ $3\left[\mathrm{M}\left(m-\mathrm{C}_{6} \mathrm{H}_{4}\left(\mathrm{NO}_{2}\right) \mathrm{COO}\right)_{2}\left(\mathrm{~N}_{2} \mathrm{H}_{4}\right)_{2}\right]+6 \mathrm{~N}_{2} \mathrm{H}_{5} \mathrm{NO}_{3}+(3 \mathrm{n}+12) \mathrm{H}_{2} \mathrm{O}$ where $\mathrm{M}=\mathrm{Co}, \mathrm{Ni}, \mathrm{Zn}$ or $\mathrm{Cd}$

$2 \mathrm{Co}\left(\mathrm{NO}_{3}\right)_{2} \cdot 6 \mathrm{H}_{2} \mathrm{O}+\mathrm{M}\left(\mathrm{NO}_{3}\right)_{2} \cdot \mathrm{xH}_{2} \mathrm{O}+6 \mathrm{C}_{6} \mathrm{H}_{4}\left(\mathrm{NO}_{2}\right) \mathrm{COOH}$ $+12 \mathrm{~N}_{2} \mathrm{H}_{4} \cdot \mathrm{H}_{2} \mathrm{O} \rightarrow\left[\mathrm{MCo}_{2}\left(m-\mathrm{C}_{6} \mathrm{H}_{4}\left(\mathrm{NO}_{2}\right) \mathrm{COO}\right)_{6}\left(\mathrm{~N}_{2} \mathrm{H}_{4}\right)_{6}\right]$

$+6 \mathrm{~N}_{2} \mathrm{H}_{5} \mathrm{NO}_{3}+(\mathrm{x}+24) \mathrm{H}_{2} \mathrm{O}$

where $\mathrm{M}=\mathrm{Ni}, \mathrm{Zn}$ or $\mathrm{Cd}$

These complexes are stable in air, insoluble in water and organic solvents such as alcohol and ether. The compositions of the complexes were assigned on the basis of hydrazine and metal analyses. The analytical data of these complexes are summarized in Table-1.

Magnetic moments and electronic spectra: The magnetic moments of the cobalt and nickel complexes were found to be 4.8 BM and 3.1 BM, respectively. These values are in accordance with the high spin nature of $\mathrm{Co}$ (II) and $\mathrm{Ni}$ (II) ions. As expected $\mathrm{Zn}$ (II) and $\mathrm{Cd}(\mathrm{II})$ complexes are diamagnetic. The electronic spectra of cobalt complex shows a band at 23,500 $\mathrm{cm}^{-1}$ which is assigned to ${ }^{4} \mathrm{~T}_{1 \mathrm{~g}}(\mathrm{~F}) \rightarrow{ }^{4} \mathrm{~T}_{1 \mathrm{~g}}(\mathrm{P})$ transition. The nickel complex shows two bands at $14,300 \mathrm{~cm}^{-1}$ and 20,400 $\mathrm{cm}^{-1}$ which are assigned to ${ }^{3} \mathrm{~A}_{2 \mathrm{~g}} \rightarrow{ }^{3} \mathrm{~T}_{1 \mathrm{~g}}(\mathrm{~F})$ and ${ }^{3} \mathrm{~A}_{2 \mathrm{~g}} \rightarrow{ }^{3} \mathrm{~T}_{1 \mathrm{~g}}(\mathrm{P})$ transitions, respectively, which are characteristics of octahedral geometry around $\mathrm{Co}(\mathrm{II})$ and $\mathrm{Ni}(\mathrm{II})$ ions $^{27}$.

Infrared spectra: All the bis-hydrazine metal and mixed metal complexes show similar IR spectra which are almost superimposable. All the complexes show bands in the region $3650-3700 \mathrm{~cm}^{-1}$ due to the N-H stretching of hydrazine molecules. The $v_{\text {asy }}$ and $v_{\text {sym }}$ stretching of carboxylate ions are observed in the regions $1600-1620$ and $1380-1390 \mathrm{~cm}^{-1}$ respectively with $\Delta v$ separation $>200 \mathrm{~cm}^{-1}$ which clearly indicates the monodentate coordination of carboxylate ions ${ }^{28}$. The N-N stretching frequencies of hydrazine moieties are observed in the region $960-950 \mathrm{~cm}^{-1}$ and are in conformity with the bidentate bridging nature of hydrazine ${ }^{29}$. The bands at 1540-1530 and

TABLE-1

ANALYTICAL DATA OF THE COMPOUNDS

\begin{tabular}{|c|c|c|c|c|c|c|c|}
\hline \multirow{2}{*}{ m.f. } & \multirow{2}{*}{ m.w. } & \multicolumn{2}{|c|}{ Hydrazine } & \multicolumn{3}{|c|}{ Elemental analysis (\%): Found (calcd.) } & \multirow{2}{*}{ Yield $(\%)$} \\
\hline & & Found & Calcd. & $\mathrm{C}$ & $\mathrm{H}$ & $\mathrm{N}$ & \\
\hline $\mathrm{Co}\left(m-\mathrm{C}_{6} \mathrm{H}_{4}\left(\mathrm{NO}_{2}\right) \mathrm{COO}\right)_{2}\left(\mathrm{~N}_{2} \mathrm{H}_{4}\right)_{2}$ & 455.26 & 13.50 & 14.08 & $36.22(36.94)$ & $3.60(3.54)$ & $18.04(18.46)$ & 90 \\
\hline $\mathrm{Ni}\left(m-\mathrm{C}_{6} \mathrm{H}_{4}\left(\mathrm{NO}_{2}\right) \mathrm{COO}\right)_{2}\left(\mathrm{~N}_{2} \mathrm{H}_{4}\right)_{2}$ & 455.01 & 13.62 & 14.09 & $36.52(36.96)$ & $3.38(3.54)$ & $18.14(18.47)$ & 85 \\
\hline $\mathrm{Zn}\left(m-\mathrm{C}_{6} \mathrm{H}_{4}\left(\mathrm{NO}_{2}\right) \mathrm{COO}\right)_{2}\left(\mathrm{~N}_{2} \mathrm{H}_{4}\right)_{2}$ & 461.71 & 13.20 & 13.88 & $36.19(36.42)$ & $3.54(3.49)$ & $18.32(18.20)$ & 90 \\
\hline $\mathrm{Cd}\left(m-\mathrm{C}_{6} \mathrm{H}_{4}\left(\mathrm{NO}_{2}\right) \mathrm{COO}\right)_{2}\left(\mathrm{~N}_{2} \mathrm{H}_{4}\right)_{2}$ & 508.72 & 12.34 & 12.60 & $33.50(33.05)$ & $3.07(3.17)$ & $16.22(16.52)$ & 85 \\
\hline $\mathrm{Co}_{2 / 3} \mathrm{Ni}_{1 / 3}\left(m-\mathrm{C}_{6} \mathrm{H}_{4}\left(\mathrm{NO}_{2}\right) \mathrm{COO}\right)_{2}\left(\mathrm{~N}_{2} \mathrm{H}_{4}\right)_{2}$ & 455.18 & 13.82 & 14.08 & $36.25(36.94)$ & $3.33(3.54)$ & $18.08(18.46)$ & 80 \\
\hline $\mathrm{Co}_{2 / 3} \mathrm{Zn}_{1 / 3}\left(m-\mathrm{C}_{6} \mathrm{H}_{4}\left(\mathrm{NO}_{2}\right) \mathrm{COO}\right)_{2}\left(\mathrm{~N}_{2} \mathrm{H}_{4}\right)_{2}$ & 457.41 & 13.65 & 14.01 & $36.50(36.76)$ & $3.60(3.53)$ & $18.88(18.37)$ & 85 \\
\hline $\mathrm{Co}_{2 / 3} \mathrm{Cd}_{1 / 3}\left(m-\mathrm{C}_{6} \mathrm{H}_{4}\left(\mathrm{NO}_{2}\right) \mathrm{COO}\right)_{2}\left(\mathrm{~N}_{2} \mathrm{H}_{4}\right)_{2}$ & 473.08 & 13.14 & 13.55 & $35.80(35.54)$ & $3.81(3.41)$ & $17.80(17.78)$ & 83 \\
\hline
\end{tabular}


$1350-1340 \mathrm{~cm}^{-1}$ were assigned to asymmetric and symmetric vibrations of the $\mathrm{NO}_{2}$ group. The IR spectra of zinc and cobaltnickel mixed metal complexes are given in Fig. 1 and 2 as representative examples.

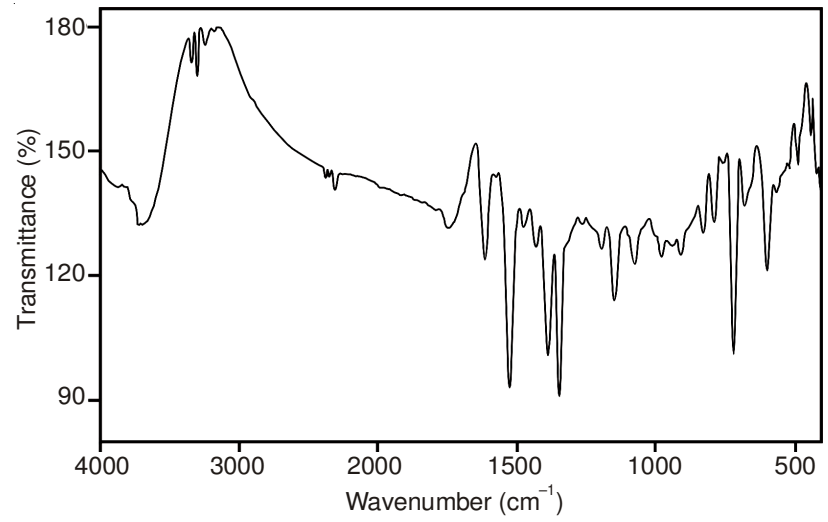

Fig. 1. IR Spectrum of $\mathrm{Zn}\left(m-\mathrm{C}_{6} \mathrm{H}_{4}\left(\mathrm{NO}_{2}\right) \mathrm{COO}\right)_{2}\left(\mathrm{~N}_{2} \mathrm{H}_{4}\right)_{2}$

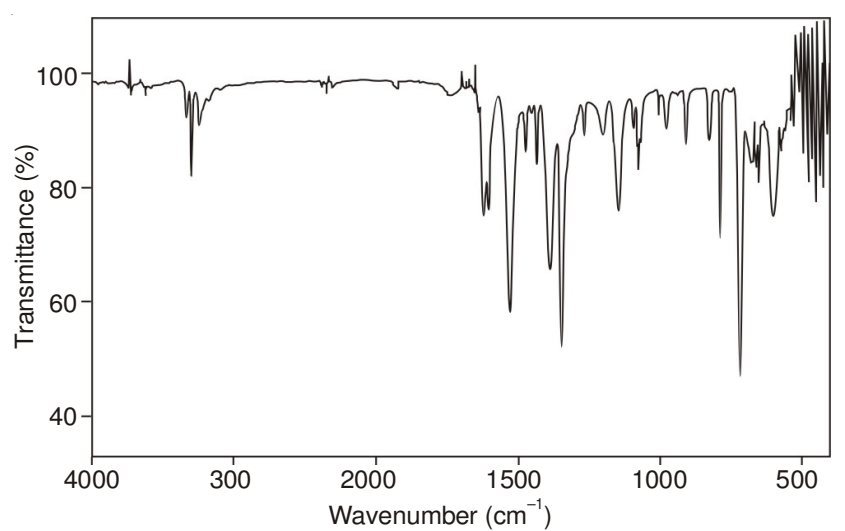

Fig. 2. IR spectrum of $\mathrm{Co}_{2} /{ }_{3} \mathrm{Ni}_{1 / 3}\left(m-\mathrm{C}_{6} \mathrm{H}_{4}\left(\mathrm{NO}_{2}\right) \mathrm{COO}\right)_{2}\left(\mathrm{~N}_{2} \mathrm{H}_{4}\right)_{2}$

Thermal degradation: Hydrazine is sensitive to heat due to the presence of endothermic N-N bond. The nitro group is also capable of enhancing the thermal reactivity, hence the present series of complexes are expected to decompose exothermically and vigorously at lower temperature. The bishydrazine cobalt $m$-nitrobenzoate decomposes in a single step in the temperature range $225-270{ }^{\circ} \mathrm{C}$ results in the formation of $\mathrm{Co}_{2} \mathrm{O}_{3}$ as final residue. DTA shows an exotherm at $220{ }^{\circ} \mathrm{C}$ corresponding to this step. The nickel(II) complex decomposes similar to the cobalt(II) complex in single step between 280$300{ }^{\circ} \mathrm{C}$ to give $\mathrm{NiO}$ as the end product. The DTA shows a sharp exotherm at $295^{\circ} \mathrm{C}$ for the above step. The zinc(II) complex undergoes decomposition in a different pattern in this series. It decomposes in two stages, both sharp exothermic with the
DTA peak temperatures 240 and $420^{\circ} \mathrm{C}$. The first step corresponding to the loss of two hydrazine molecules to give zinc $m$-nitro-benzoate as the intermediate which further decomposes in the temperature range $350-450{ }^{\circ} \mathrm{C}$ to give $\mathrm{ZnO}$ as the final residue.

The single step decomposition of cadmium(II) complex was also observed which leads to the formation of cadmium oxide. DTA shows an exotherm at $240{ }^{\circ} \mathrm{C}$. The TG mass loss is observed in the temperature range $200-250{ }^{\circ} \mathrm{C}$ is $76 \%$ which is close to the theoretical value.

The thermal degradation pattern of all the bis-hydrazine mixed metal $m$-nitrobenzoate complexes shows single step decomposition in the temperature range $250-300{ }^{\circ} \mathrm{C}$ with DTA peak temperatures around $260^{\circ} \mathrm{C}$. The simultaneous TG-DTA of nickel and zinc complexes are given in Figs. 3 and 4 respectively. The thermal degradation data of the complexes are given in Table-2.

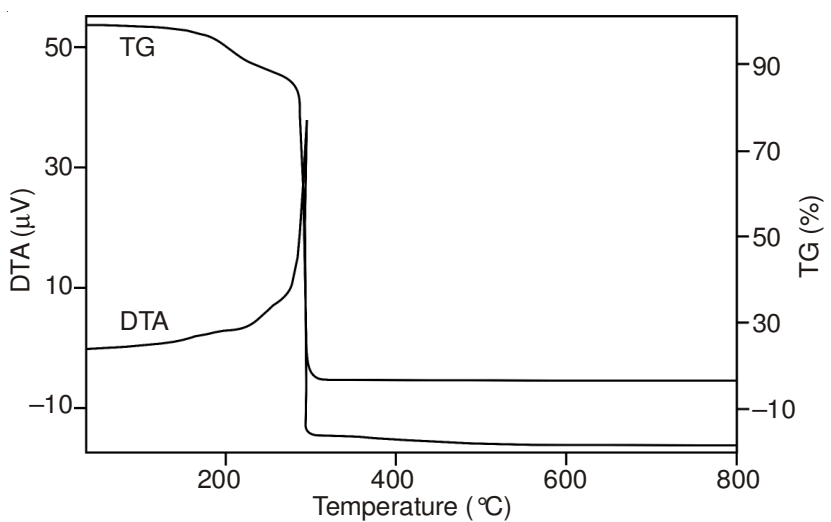

Fig. 3. Simultaneous TG-DTA of $\mathrm{Ni}\left(m-\mathrm{C}_{6} \mathrm{H}_{4}\left(\mathrm{NO}_{2}\right) \mathrm{COO}\right)_{2}\left(\mathrm{~N}_{2} \mathrm{H}_{4}\right)_{2}$

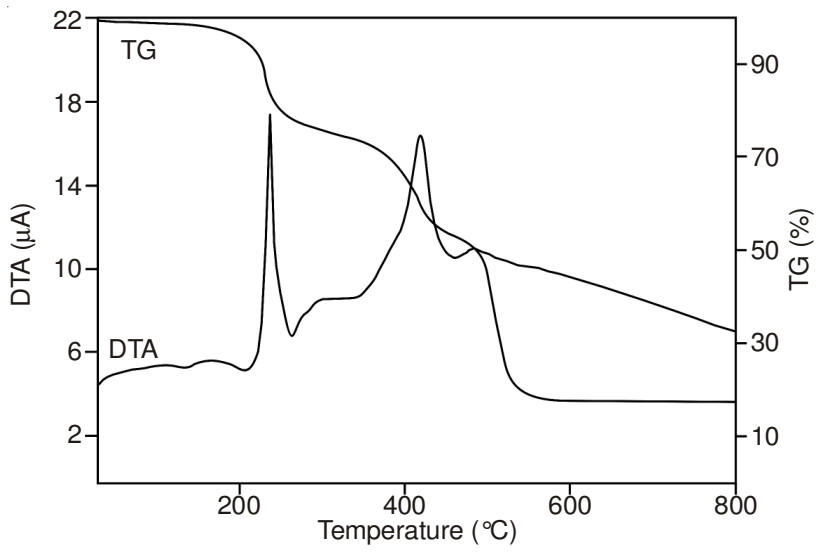

Fig. 4. Simultaneous TG-DTA of $\mathrm{Zn}\left(m-\mathrm{C}_{6} \mathrm{H}_{4}\left(\mathrm{NO}_{2}\right) \mathrm{COO}\right)_{2}\left(\mathrm{~N}_{2} \mathrm{H}_{4}\right)_{2}$

\begin{tabular}{|c|c|c|c|c|}
\hline \multicolumn{5}{|c|}{$\begin{array}{c}\text { TABLE-2 } \\
\text { SIMULTANEOUS TG-DTA ANALYSIS DATA }\end{array}$} \\
\hline Compound & $\begin{array}{c}\text { DTA } \\
\text { Peak temp. }\left({ }^{\circ} \mathrm{C}\right)\end{array}$ & $\begin{array}{c}\text { TG } \\
\text { Temp. range }\left({ }^{\circ} \mathrm{C}\right)\end{array}$ & $\begin{array}{l}\text { Weight loss } \\
\text { Found (calcd.) }\end{array}$ & Residue \\
\hline $\mathrm{Co}\left(m-\mathrm{C}_{6} \mathrm{H}_{4}\left(\mathrm{NO}_{2}\right) \mathrm{COO}\right)_{2}\left(\mathrm{~N}_{2} \mathrm{H}_{4}\right)_{2}$ & 255 (exo) & $225-270$ & $80.50(81.80)$ & $\mathrm{Co}_{2} \mathrm{O}_{3}$ \\
\hline $\mathrm{Ni}\left(m-\mathrm{C}_{6} \mathrm{H}_{4}\left(\mathrm{NO}_{2}\right) \mathrm{COO}\right)_{2}\left(\mathrm{~N}_{2} \mathrm{H}_{4}\right)_{2}$ & 295 (exo) & $280-300$ & $84.40(83.59)$ & $\mathrm{NiO}$ \\
\hline $\mathrm{Zn}\left(m-\mathrm{C}_{6} \mathrm{H}_{4}\left(\mathrm{NO}_{2}\right) \mathrm{COO}\right)_{2}\left(\mathrm{~N}_{2} \mathrm{H}_{4}\right)_{2}$ & 240 (exo) & $200-275$ & $14.80(13.88)$ & $\mathrm{Zn}\left(m-\mathrm{C}_{6} \mathrm{H}_{4}\left(\mathrm{NO}_{2}\right) \mathrm{COO}\right)_{2}$ \\
\hline & 420 (exo) & $350-450$ & $82.00(82.37)$ & $\mathrm{ZnO}$ \\
\hline $\mathrm{Cd}\left(m-\mathrm{C}_{6} \mathrm{H}_{4}\left(\mathrm{NO}_{2}\right) \mathrm{COO}\right)_{2}\left(\mathrm{~N}_{2} \mathrm{H}_{4}\right)_{2}$ & 240 (exo) & $200-250$ & $75.90(74.76)$ & $\mathrm{CdO}$ \\
\hline $\mathrm{Co}_{2 / 3} \mathrm{Ni}_{1 / 3}\left(m-\mathrm{C}_{6} \mathrm{H}_{4}\left(\mathrm{NO}_{2}\right) \mathrm{COO}\right)_{2}\left(\mathrm{~N}_{2} \mathrm{H}_{4}\right)_{2}$ & 260 (exo) & $250-270$ & $82.10(82.38)$ & $\mathrm{NiCO}_{2} \mathrm{O}_{4}$ \\
\hline $\mathrm{Co}_{2 / 3} \mathrm{Zn}_{1 / 3}\left(m-\mathrm{C}_{6} \mathrm{H}_{4}\left(\mathrm{NO}_{2}\right) \mathrm{COO}\right)_{2}\left(\mathrm{~N}_{2} \mathrm{H}_{4}\right)_{2}$ & 265 (exo) & $260-280$ & $82.80(81.98)$ & $\mathrm{ZnCo}_{2} \mathrm{O}_{4}$ \\
\hline $\mathrm{Co}_{2 / 3} \mathrm{Cd}_{1 / 3}\left(m-\mathrm{C}_{6} \mathrm{H}_{4}\left(\mathrm{NO}_{2}\right) \mathrm{COO}\right)_{2}\left(\mathrm{~N}_{2} \mathrm{H}_{4}\right)_{2}$ & 263 (exo) & $250-280$ & $81.10(79.27)$ & $\mathrm{CdCo}_{2} \mathrm{O}_{4}$ \\
\hline
\end{tabular}


$\mathrm{X}$-ray powder diffraction: The isomorphism among the series of complexes is confirmed by their X-ray patterns, which are almost superimposable. The X-ray powder patterns of the mixed metal complexes shows sharp peaks which are identical with the simple complexes confirming the formation of solid solutions. The 'd' value for cadmium, zinc and cobalt-nickel mixed metal complexes are given in Table-3. The X-ray powder diffraction patterns of zinc(II) and cadmium(II) complexes are shown in Figs. 5 and 6, respectively.

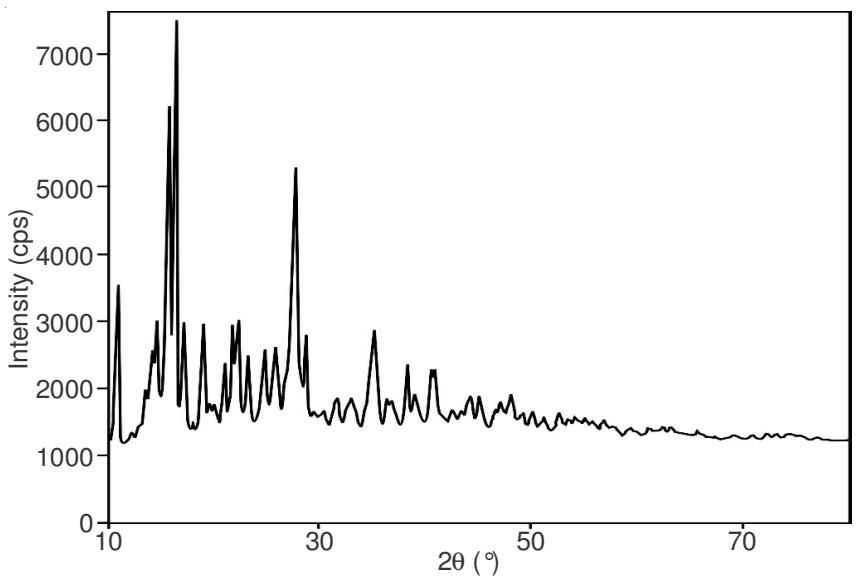

Fig. 5. X-ray powder diffraction pattern of $\mathrm{Zn}\left(m-\mathrm{C}_{6} \mathrm{H}_{4}\left(\mathrm{NO}_{2}\right) \mathrm{COO}\right)_{2}\left(\mathrm{~N}_{2} \mathrm{H}_{4}\right)_{2}$

Metal cobaltites: The metal cobaltites were prepared by slowly heating the respective mixed metal complexes in a closed silica crucible at $260{ }^{\circ} \mathrm{C}$ for $10 \mathrm{~min}$. The products formed were confirmed by their IR spectra and X-ray powder diffraction patterns. The metal analyses clearly indicate the ratios between cobalt to metal in the complexes are 1.98 to 2.1. The analytical, spectral and X-ray powder data of the metal cobaltites are summarised in Table-4. The line broadening indicates the fine particle nature of these cobaltites. The cell

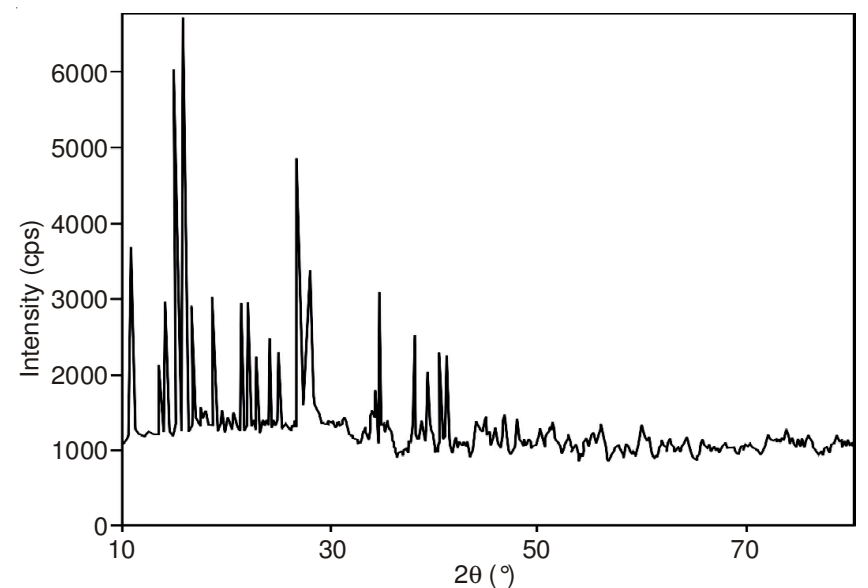

Fig. 6. X-ray powder diffraction pattern of $\mathrm{Cd}\left(m-\mathrm{C}_{6} \mathrm{H}_{4}\left(\mathrm{NO}_{2}\right) \mathrm{COO}\right)_{2}\left(\mathrm{~N}_{2} \mathrm{H}_{4}\right)_{2}$

parameter 'a' calculated from the X-ray powder diffraction patterns are also presented in Table-4. The X-ray powder diffraction pattern of nickel cobaltite is shown in Fig. 7.

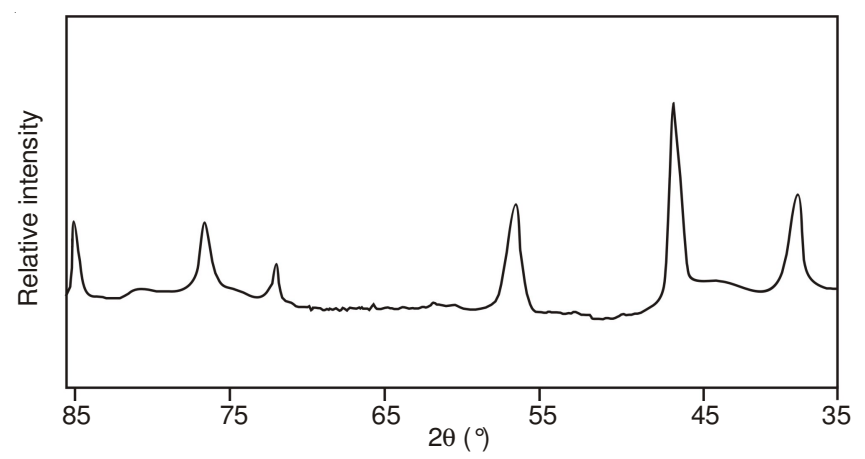

Fig. 7. X-ray powder diffraction pattern of $\mathrm{NiCO}_{2} \mathrm{O}_{4}$

\begin{tabular}{|c|c|c|c|c|c|c|c|c|}
\hline \multicolumn{9}{|c|}{$\begin{array}{c}\text { TABLE-3 } \\
\text { X-RAY POWDER DIFFRACTION DATA }\end{array}$} \\
\hline \multicolumn{3}{|c|}{$\mathrm{Cd}\left(m-\mathrm{C}_{6} \mathrm{H}_{4}\left(\mathrm{NO}_{2}\right) \mathrm{COO}\right)_{2}\left(\mathrm{~N}_{2} \mathrm{H}_{4}\right)_{2}$} & \multicolumn{3}{|c|}{$\mathrm{Zn}\left(m-\mathrm{C}_{6} \mathrm{H}_{4}\left(\mathrm{NO}_{2}\right) \mathrm{COO}\right)_{2}\left(\mathrm{~N}_{2} \mathrm{H}_{4}\right)_{2}$} & \multicolumn{3}{|c|}{$\mathrm{Co}_{2 / 3} \mathrm{Ni}_{1 / 3}\left(m-\mathrm{C}_{6} \mathrm{H}_{4}\left(\mathrm{NO}_{2}\right) \mathrm{COO}\right)_{2}\left(\mathrm{~N}_{2} \mathrm{H}_{4}\right)_{2}$} \\
\hline $2 \theta$ & Intensity & $\mathrm{d}$ value & $2 \theta$ & Intensity & d value & $2 \theta$ & Intensity & $\mathrm{d}$ value \\
\hline 10.52 & 100 & 8.4025 & 10.76 & 47 & 8.2156 & 10.52 & 94.6 & 8.4025 \\
\hline 11.28 & 92.6 & 7.8380 & 13.48 & 26.3 & 6.5633 & 11.49 & 100 & 7.6952 \\
\hline 14.88 & 61.4 & 5.9488 & 14 & 34.6 & 6.3207 & 14.05 & 100 & 6.2983 \\
\hline 15.2 & 58.4 & 5.8243 & 14.5 & 40.2 & 6.1039 & 14.7 & 95.7 & 6.0213 \\
\hline 15.97 & 54 & 5.5452 & 15.5 & 82.7 & 5.7122 & 15.34 & 92.4 & 5.7715 \\
\hline 16.4 & 52.6 & 5.4007 & 16.1 & 100 & 5.5007 & 16.1 & 89.1 & 5.5007 \\
\hline 17.2 & 48 & 5.1513 & 17 & 39.7 & 5.2114 & 16.46 & 96.7 & 5.3812 \\
\hline 18.44 & 42.9 & 4.8076 & 18.9 & 39.5 & 4.6916 & 17.4 & 78.3 & 5.0925 \\
\hline 19.24 & 39.7 & 4.6095 & 20.9 & 32 & 4.2469 & 18.32 & 70.7 & 4.8388 \\
\hline 21.11 & 35.8 & 4.2052 & 21.71 & 39.4 & 4.0903 & 21 & 65.2 & 4.2269 \\
\hline 22.75 & 31.1 & 3.9056 & 22.2 & 40.1 & 4.0011 & 22.49 & 66.3 & 3.9502 \\
\hline 24.46 & 30.1 & 3.6363 & 23.1 & 33.1 & 3.8472 & 23.8 & 67.4 & 3.7356 \\
\hline 28.3 & 33.1 & 3.1510 & 24.75 & 34.6 & 3.5943 & 25.8 & 69.6 & 3.4504 \\
\hline 31.27 & 22.1 & 2.8582 & 25.7 & 35.1 & 3.4636 & 27.81 & 69.6 & 3.2054 \\
\hline 34.43 & 27.8 & 2.6027 & 27.48 & 70.9 & 3.2431 & 30 & 53.3 & 2.9762 \\
\hline 38.05 & 22.8 & 2.3630 & 28.62 & 37.5 & 3.1165 & 32.8 & 51.1 & 2.7283 \\
\hline 39.4 & 24.7 & 2.2851 & 35.08 & 38.3 & 2.5560 & 34.49 & 48.9 & 2.5983 \\
\hline 41.3 & 19.5 & 2.1843 & 38.16 & 31.6 & 2.3565 & 36.1 & 46.7 & 2.4861 \\
\hline 45.6 & 22.1 & 1.9878 & 40.45 & 30.4 & 2.2282 & 39.3 & 45.7 & 2.2907 \\
\hline 48.09 & 21.4 & 1.8905 & 47.98 & 25.6 & 1.8946 & 50.1 & 48.9 & 1.8193 \\
\hline
\end{tabular}




\begin{tabular}{|c|c|c|c|c|c|c|c|c|}
\hline \multirow{3}{*}{ S. No } & & \multicolumn{6}{|c|}{$\begin{array}{c}\text { TABLE-4 } \\
\text { ANALYTICAL AND SPECTRAL DATA OF METAL COBALTITES }\end{array}$} & \multirow{3}{*}{$\mathrm{XRD}(\AA)$} \\
\hline & \multirow{2}{*}{ Oxide } & \multicolumn{2}{|c|}{ Cobalt $(\%)$} & \multicolumn{2}{|c|}{ Metal (\%) } & \multicolumn{2}{|c|}{ IR Spectra $\left(\mathrm{cm}^{-1}\right)$} & \\
\hline & & Found. & Calc. & Found. & Calc. & $v_{1}$ & $v_{2}$ & \\
\hline 1 & $\mathrm{NiCo}_{2} \mathrm{O}_{4}$ & 49.20 & 49.00 & 24.80 & 24.40 & 660 & 565 & 8.098 \\
\hline 2 & $\mathrm{ZnCo}_{2} \mathrm{O}_{4}$ & 46.90 & 47.67 & 26.00 & 26.45 & 665 & 560 & 8.120 \\
\hline 3 & $\mathrm{CdCo}_{2} \mathrm{O}_{4}$ & 39.60 & 40.05 & 38.50 & 38.22 & 660 & 555 & 8.110 \\
\hline
\end{tabular}

\section{REFERENCES}

1. Ye-Dan Shen and Jian-Li Lin, Z. kristallogr. NCS, 228, 25 (2013)

2. B.R. Srinivasan, J.V. Sawant, C. Näther and W. Bensch, J. Chem. Sci., 119, 243 (2007).

3. J. Medvecka, J. Moncol, V. Jorik and D. Valigura, Acta Chim. Slov., 3, 73 (2010)

4. B.R. Srinivasan and G.K. Rane, J. Chem. Sci., 121, 145 (2009).

5. F. Hu, X. Yin, Y. Feng, Y. Mi and S. Zhang, Acta Crystallogr., 65E, m210 (2009).

6. W. Ferenc, A. Walków-Dziewulska, B. Cristóvão and J. Sarzyñski, J. Serb. Chem. Soc., 71, 929 (2006).

7. Z. Vaskova, P. Stachova, L. Krupkova, D. Hudecova and D. Valigura, Acta Chimica slovaca, 2, 77 (2009).

8. B.N. Sivasankar and S. Govindarajan, J. Therm. Anal., 46, 117 (1996).

9. B.N. Sivasankar and S. Govindarajan, Inorg. Met.- Org.Chem., 24, 1573 (1994).

10. B.N. Sivasankar, J. Therm. Anal. Calorim., 86, 385 (2006).

11. S. Yasodhai and S. Govindarajan, Synt. React. Inorg. Met.- Org. Chem., 29, 919 (1999).

12. B.N. Sivasankar and S. Govindarajan, Synt. React. Inorg. Met.- Org. Chem., 24, 1573 (1994).

13. S. Yasodhai and S. Govindarajan, J. Therm. Anal. Calorim., 62, 737 (2000)

14. S. Yasodhai, T. Sivakumar and S. Govindarajan, Thermochim. Acta, 338, 57 (1997)
15. L. Vikram and B.N. Sivasankar, Indian J. Chem., 47A, 25 (2008).

16. O. Gencova and J. Šiftar, J. Therm. Anal. Calorim., 57, 591 (1999).

17. R. Raju and B.N. Sivasankar, J. Therm. Anal. Calorim., 98, 371 (2009).

18. K. Kuppusamy and S. Govindarajan, Eur. J. Solid State Inorg. Chem., 32, 997 (1995).

19. K. Kuppusamy and S. Govindarajan, Synt. React. Inorg. Met.-Org. Chem., 26, 225 (1996).

20. K. Kuppusamy and S. Govindarajan, Thermochim. Acta, 274, 125 (1996).

21. B.N. Sivasankar and S. Govindarajan, Indian J. Chem., 33A, 329 (1994).

22. B. N. Sivasankar and S. Govindarajan, Z. Naturforsch, 49b, 950 (1994).

23. S. Yasodhai and S. Govindarajan, Indian J. Chem., 38A, 1244 (1999).

24. L. Vikram and B.N. Sivasankar, Thermochim. Acta, 452, 20 (2007).

25. I.A. Vogal, A Text Book of Quantitative Inorganic Analysis, Longmans, London, edn 2 (1951)

26. L. Erdey, Edited by I Buzas, Gravimetric Analysis, Part II, Chap. 23, Pergamon, London (1965).

27. A.B.P. Lever, Inorganic Electronic Spectroscopy, Elsevier, Amsterdam, edn 2 (1984).

28. K. Nakamoto, Infrared and Raman Spectra of Inorganic and Coordination Compounds, Wiley/ Interscience, New York, edn 3 (1978).

29. A. Braibanti, F. Dallavalle, M.A. Pellinghelli and E. Leporati, Inorg. Chem., 7, 1430 (1968). 